\title{
IMPLEMENTASI STRATEGI PEMBINAAN \\ MENUJU PERTUMBUHAN ROHANI PEMUDA GKII JEMAAT SIDU'UNG MUARA BERAU
}

\author{
Mika $^{1}$ \\ Petronella Tuhumury ${ }^{2}$ \\ sttjaffraymakassar@yahoo.co.id
}

Tujuan karya ilmiah ini adalah Pertama, menemukan faktor-faktor penyebab serta masalah pemuda Jemaat Sidu'ung tidak mengalami pertumbuhan rohani. Kedua, memberikan strategi yang efektif untuk meningkatkan pembinaan terhadap pemuda sehingga mengalami pertumbuhan rohani.

Metode yang digunakan dalam penyusuanan karya ilmiah ini adalah: Pertama, penelitian kepustakaan yaitu mengumpulkan data dari kamus, Alkitab, buku-buku, majalah, koran, diktat. Kedua, melalui wawancara responden, kuisioner untuk memperoleh informasi sebagai data lapangan.

Kesimpulan karya ilmiah ini adalah: Pertama, penghambat pertumbuhan rohani pemuda GKII Sidu'ung Muara adalah karena belum terjadi pertobatan yang sesungguhnya di kalangan pemuda. Kedua, fakta di lapangan menunjukkan adanya kendala-kendala yang menghambat dalam pertumbuhan rohani pemuda GKII Sidu'ung Muara yaitu: 1) kurangnya dedikasi seorang Pembina pemuda terhadap pelayanan pemuda. 2) Kurangnya persekutuan. 3) Lingkungan sosial yang kurang mendukung pertumbuhan rohani pemuda. 4) Program pelayanan pemuda kurang menarik. Ketiga, beberapa upaya atau strategi pembinaan yang efektif dalam meningkatkan kualitas kerohanian pemuda adalah dengan melakukan perkunjungan secara teratur, melalui pemahaman Alkitab, mengadakan retret, menyelenggarakan KKR, Penginjilan Pribadi dan menata persekutuan dengan kreatif.

Kata kunci: implementasi, strategi pembinaan, pertumbuhan rohani

\footnotetext{
${ }^{1}$ Alumni S1 STT Jaffray Makassar 2013

${ }^{2}$ Dosen Pendidikan Agama Kristen STT Jaffray Makassar
} 


\section{PENDAHULUAN}

\section{Latar Belakang Masalah}

Perkembangan zaman yang begitu pesat sangat memengaruhi kehidupan manusia khususnya kaum muda Kristen sehingga sering terdengar dan terlihat kenyataan di lapangan saat ini norma yang menjadi standar hidup orang Kristen yaitu Firman Tuhan sudah tidak dilakukan atau tidak ditaati lagi. Melihat hal ini, pembinaan terhadap pertumbuhan rohani pemuda adalah sangat penting dan menjadi prioritas, supaya pemuda berdiri teguh di atas kebenaran Firman Tuhan serta menyadari tugas dan tanggung jawabnya sebagai generasi penerus yang merupakan harapan gereja dan negara.

Melihat peranan kaum muda dalam gereja sangat penting dan sangat menentukan masa depan gereja, maka perlu adanya pembinaan yang serius terhadap pertumbuhan kerohanian pemuda. Pembinaan yang dimaksudkan adalah suatu usaha yang dilakukan untuk membimbing dan menolong setiap pemuda dalam pembentukan kepribadiannya yang sesuai dengan standar Firman Tuhan. Pembinaan rohani ini sangat penting karena masa muda adalah masa transisi di mana kaum muda sangat membutuhkan bimbingan. Charles M Shelton mengatakan:

Masa muda adalah proses peralihan masa kanak-kanak menuju masa dewasa, suatu masa yang menentukan perkembangan manusia di bidang emosional, moral spiritual dan fisik. Masa muda ini adalah masa perkembangan dan perubahan, masa goncang dan penuh pemberontakan. Tidak jarang kita temui banyak kaum muda kehilangan pegangan dalam usaha menemukan dirinya. Dalam masa ini kaum muda memang membutuhkan pendampingan kaum dewasa, yang bisa memahami dan melindungi mereka tumbuh dewasa. ${ }^{3}$

Dengan keadaan seperti ini penting adanya pembinaan terhadap generasi muda, karena generasi muda merupakan pemegang kendali terhadap arah pelayanan ke depan. Apabila generasi muda dibina dengan baik maka gereja akan bisa maju dan berkembang. Sebaliknya jika gereja lalai dalam pembinaan kaum muda maka pasti keadaan pelayanan gereja akan mengalami kemunduran sehingga memengaruhi kehidupan rohani jemaat.

Tidak dipungkiri dewasa ini fakta yang ada berdasarkan pengamatan penulis, gereja kurang memberikan perhatian terhadap kaum muda sehingga pembinaan kerohanian pemuda tidak maksimal,

\footnotetext{
${ }^{3}$ Charles M. Shelton, Moralitas Kaum Muda (Yogyakarta: Kanisius, 1990), 5.
} 
termasuk di pemuda Gereja Kemah Injil Indonesia jemaat Sidu'ung Muara Kalimantan Timur. Walaupun ada pembinaan terhadap pemuda tetapi tidak ada tanda pertumbuhan yang menunjukan bahwa mereka adalah pemuda Kristen. Pembinaan tidak maksimal, atau pembinaan yang ada kurang diperhatikan dengan serius. Dengan sangat kurangnya pelaksanaan pembinaan terhadap pemuda sehingga pemuda tidak mengalami pertumbuhan secara rohani. Hal ini terlihat dalam perilaku dan sikap hidup yang terlibat dalam pergaulan yang tidak baik misalnya merokok, minum minuman beralkohol dan jarang mengikuti persekutuan. Hal seperti ini mengakibatkan terjadinya pergeseran nilai di mana kehidupan moral kaum muda menjadi rusak. Meskipun mereka lahir dan dibesarkan dalam keluarga Kristen, namun kehidupan mereka setiap hari sangat bertentangan dengan kebenaran Firman Tuhan.

Faktor penghambat pertumbuhan rohani pemuda jemaat Sidu'ung Muara, Berau adalah sebagai berikut:

Pertama, belum lahir baru. Berbicara mengenai belum lahir baru tidak seorang pun yang mengetahui kapan seseorang lahir baru hanya pribadi orang itu dengan Tuhan yang tahu orang itu telah lahir baru. Namun demikian seseorang yang dikatakan belum dan sudah lahir baru dapat dilihat dari perbuatan, tingkah laku, kasih orang itu kepada Tuhan dan kepada sesama manusia.

Kedua, kurangnya dedikasi seorang pembina pemuda. Ibu Ulan (samaran), mengatakan "Sangat sulit untuk menilai pemimpin pemuda saat ini, perhatiannya kepada anggota pemuda sangatlah tidak terlihat, baik dalam persekutuannya maupun dalam hal-hal rohani." ${ }^{4}$ Hal yang sama juga diungkapkan oleh ketua pemuda saat ini, "Pemimpin pemuda sama sekali tidak ada pendekatannya terhadap anggota pemuda."

Mengacu kepada pernyataan di atas membuktikan bahwa kepemimpinan yang ada dalam persekutuan pemuda khususnya yang ada di jemaat Sidu'ung Muara Berau menunjukkan bahwa pemimpin itu sendiri tidak memperhatikan kebutuhan anggota kelompoknya.

Ketiga, kurangnya persekutuan. Dari pengamatan dan hasil wawancara penulis dengan beberapa anggota pemuda keterlibatan dalam persekutuan sangat kurang sekali. Dalam wawancara penulis dengan Kule (samaran), ia mengatakan:

Pemuda yang ada dalam jemaat Sidu'ung Muara terbilang banyak jumlahnya tapi rata-rata kehadiran mereka dalam persekutuan pemuda sangatlah kurang. SebagAi contoh: mereka mengetahui

\footnotetext{
${ }^{4}$ Ulan, wawancara oleh penulis, Sidu'ung Muara Kalimantan Timur, 5 Juni 2013.

${ }^{5}$ Ketua pemuda sidu'ung Muara, wawancara oleh Penulis, Sidu'ung Muara, Kalimantan Timur 5 juni 2013.
} 
bahwa pada hari Sabtu pukul 19:30 adalah kebaktian pemuda tetapi pada saat persekutuan itu sudah dilakukan kehadiran setiap anggotanya sedikit sekali yang hadir. ${ }^{6}$

Kecenderungan dari sikap pemuda yang sangat jarang mengikuti persekutuan karena mereka belum mengerti pentingnya persekutuan, di samping itu juga sifat mendahulukan kepentingan pribadi masih ada dikalangan anggota pemuda. Ada juga sebagian anggota pemuda mengatakan bahwa sudah cukup mengikuti persekutuan pada ibadah minggu pagi saja.

Keempat, lingkungan sosial. Dari hasil wawancara dengan beberapa pemuda yang ada di Jemaat Sidu'ung Muara, bentuk pengaruh sosial ada banyak tetapi dalam bagian ini penulis akan memaparkan bentuk pengaruh sosial yang terlihat dengan jelas. Iban (samaran) berkata, "Pengaruh sosial yang terjadi dalam lingkungan pemuda saat ini dimana pemuda mudah terpengaruh dengan lingkungannya, dengan adanya televisi sebagai sarana hiburan menyebabkan mereka jarang sekali mengikuti persekutuan, ibadah pemuda."

Kelima, pelayanan yang kurang kreatif. Sulau (nama samaran) mengatakan "Kegiatan ibadah pemuda yang sangat kaku dan tidak pernah mengalami perubahan sifat kebaktian padahal dalam sebuah persekutuan bisa saja dilakukan suatu yang sifatnya baru apa lagi untuk persekutuan pemuda, hal inilah yang membuat terjadinya kebosanan pemuda dalam mengikuti persekutuan."

Dari beberapa pernyataan di atas dapat disimpulkan bahwa pelayanan yang kurang kreatif dapat membawa kejenuhan dan kebosanan bagi pemuda dalam mengikuti setiap persekutuan, meningkatkan pelayanan dalam suatu persekutuan sangat diperlukan oleh Pembina pemuda sehingga pertumbuhan rohani terjadi dalam persekutuan pemuda.

Melihat masalah dan tantangan yang ada, maka untuk dapat menjawab kebutuhan kaum muda dan memberikan landasan iman Kristen yang kuat melalui pembinaan rohani, gereja harus memikirkan dengan serius dalam membuat rancangan atau strategi pembinaan yang tepat agar pembinaan yang diberikan dapat menjawab kebutuhan kaum muda secara utuh. Berkenaan dengan itu, penulis terinspirasi dan

\footnotetext{
${ }^{6}$ Kule, pengurus Jemaat, Wawancara oleh Penulis, Sidu'ung Muara, Kalimantan Timur, 6 Juni 2013. 2013

Iban, Wawancara oleh Penulis, Sidu'ung Muara, Kalimantan Timur, 5 Juni

${ }^{8}$ Sulau, wawancara oleh Penulis, Sidu'ung Muara, Kalimantan Timur 6 Juni 2013.
} 
terdorong untuk menulis skripsi dengan judul: "Implementasi Strategi

Pembinaan Menuju Pertumbuhan Rohani Pemuda GKII Jemaat Sidu'ung Muara Berau."

\section{Pokok Masalah}

Berdasarkan latar belakang masalah di atas, maka yang menjadi pokok masalah dalam karya ilmiah ini adalah:

Pertama, apakah faktor-faktor penyebab serta masalah pemuda Jemaat Sidu'ung tidak mengalami pertumbuhan rohani? Kedua, bagaimana strategi yang efektif untuk meningkatkan pembinaan terhadap pemuda sehingga mengalami pertumbuhan rohani.

\section{Tujuan Penulisan}

Tujuan karya ilmiah ini adalah Pertama, menemukan faktor-faktor penyebab serta masalah pemuda Jemaat Sidu'ung tidak mengalami pertumbuhan rohani. Kedua, memberikan strategi yang efektif untuk meningkatkan pembinaan terhadap pemuda sehingga mengalami pertumbuhan rohani.

\section{Batasan Penulisan}

Dalam penulisan diperlukan batasan-batasan yang mempermudahkan penulis dalam meneliti dan menyusun setiap penulisan. Yang menjadi topik bahasan penulisan hanya berkisar pada pembinaan ke arah pertumbuhan rohani pemuda dan faktor-faktor penghambat pertumbuhan rohani pemuda serta strategi penanggulangannya, dan penulis membatasi penelitian pada salah satu jemaat di Gereja Kemah Injil Indonesia Jemaat Sidu'ung Muara Berau.

\section{Manfaat Penulisan}

Pertama, sebagai bahan evaluasi dan informasi dalam menunjang pertumbuhan gereja dalam meningkatkan pembinaan terhadap pemuda sehingga mengalami pertumbuhan rohani, baik secara toritis maupun praktek. Kedua, sebagai bahan acuan bagi para pemimpin atau Pembina pemuda agar memperhatikan pentingnya pelayanan pembinaan kerohanian pemuda. Ketiga, menolong pemimpin memberikan motivasi bagi para pemuda untuk bertumbuh secara rohani.

\section{Pengertian Pemuda}

Menurut Charles M. Shelton,

Definisi kaum muda dapat didasarkan pada umur kronologis, perkembangan intelektual, tingkah laku sosial ataupun 
perkembangan psikologis. Untuk mencakup semua demensi perkembangan manusia ini suatu persekutuan psikister Amerika dalam Psychiatric Glossary memberikan batasan tentang kaum muda ini sebagai berikut: Kaum muda adalah suatu priode kronologis yang dimulai dengan proses psikis dan emosional yang membawanya kematangan seksual dan psikososial, diakhiri dengan terbentuknya seorang individu yang telah mencapai kebebasan dan produktivitas sosial."

Pemuda menurut Richardson dan Raines adalah "suatu masa di mana banyak orang muda menjadikan kehidupannya suatu kegagalan dan kemalangan, karena dalam masa mudalah kebanyakan orang mengambil keputusan-keputusan yang penting dalam hidupnya."10

Dalam Kamus Besar Bahasa Indonesia, pemuda adalah "orang muda laki-laki; remaja; teruna." Namun walaupun demikian pemuda bukan hanya berpokus kepada kaum laki-laki saja tetapi ini juga mencakup sikap dan tingka laku perempuan.

Mary Go Setiawan mengkategorikan, "usia pemuda 18 sampai 24 tahun." ${ }^{2}$ Jadi kaum muda adalah golongan orang yang berada dalam posisi muda yaitu masa transisi antara anak-anak ke orang dewasa.

Berdasarkan pengertian beberapa tokoh di atas, dapat disimpulkan bahwa pemuda adalah kelompok orang yang memiliki jiwa dan semangat yang menyala-nyala serta proaktif dalam mengembangkan kemampuan atau potensi diri, sehingga mulai mengalami banyak perubahan baik secara jasmani, mental, sosial, emosional, dan spiritual. Karena pemuda sedang dalam proses perkembangan menuju penemuan diri dan kedewasaan.

\section{Tujuan Pembinaan Pemuda Kristen}

Tujuan pada umumnya memiliki arti yaitu sesuatu yang ditargetkan atau yang menjadi sasaran untuk mencapai suatu usaha atau pekerjaan. Menurut Raines dan Rihardson W., pembinaan berarti "Proses, perbuatan: sebuah cara membina dalam usaha tindakan kegiatan yang dilakukan secara berdaya guna dan berhasil guna untuk memperoleh hasil yang lebih baik."13

\footnotetext{
${ }^{9}$ Charles M. Shelton, Menuju Kedewasaan Kristen (Yogyakarta: Kanisius, 1988), 10.

${ }^{10}$ Richardson dan Raines, Asas-Asas Alkitab Bagi Kaum Muda (Bandung: Kalam Hidup, 1980), 8.

${ }^{11}$ Kamus Besar Bahasa Indonesia, s. v. "Pemuda".

${ }^{12}$ Mary Go Setiawani, Pembaharuan Mengajar (Bandung: Kalam Hidup, 2000), 33.

${ }^{13}$ Raines dan Richardso W, Azas-Azas Alkitab Bagi kaum Muda (Bandung: Kalam
} Hidup, 1995), 7. 
Pembinaan rohani pemuda Kristen berbeda dengan pembinaan rohani yang dilakukan oleh agama-agama lain di dalam dunia ini. Pembinaan pemuda Kristen memiliki tujuan meliputi beberapa hal yaitu:

\section{Tujuan Perubahan}

Dalam Roma 3 : 23, sangat jelas dikatakan bahwa semua orang telah berbuat dosa dan telah kehilangan kemuliaan Allah. Hati manusia sudah menyimpang dari Allah dan sangat bejat. Manusia bukan lagi berjalan sesuai dengan firman Tuhan melainkan hidup sesuai dengan kehendak-Nya sendiri sehingga mengakibatkan manusia menerima hukuman kematian yang kekal.

Tabiat ini telah diterima oleh manusia sejak kejatuhan manusia pertama di taman Eden. Sehingga hubungan manusia dengan Allah terputus. Hal inilah yang perlu diperbaharui, kehidupan manusia perlu diubahkan sehingga hubungan yang terputus itu dapat terjalin kembali. Pembaharuan ini meliputi perubahan status yang awalnya menjadi hamba dosa kemudian menjadi anak Allah. Sehingga manusia yang diubah statusnya menjadi anak Allah dapat mewujudkan kehidupan yang benar-benar hidup seturut kehendak Allah yaitu mencerminkan kehidupan Kristen yang sesungguhnya.

Roma 12 :2, menjelaskan "Janganlah kamu menjadi serupa dengan dunia ini, tetapi berubahlah oleh pembaharuan budimu, sehingga kamu dapat membedakan manakah kehendak Allah; apa yang baik, yang berkenan kepada Allah dan yang sempurna." Ini mengandung arti bahwa setiap manusia memerlukan perubahan yaitu hidup berkenan kepada Allah. Allah tidak menghendaki manusia hidup seperti yang dilakukan oleh orang duniawi yang penuh kejahatan.

Jadi target perubahan yang diharapkan kepada pemuda dalam pembinaan adalah tujuan pertobatan. Pertobatan yang dimaksudkan adalah seperti yang dijelaskan oleh Sinclair B. Ferguson, "Pertobatan tidak pernah hanya berupa perasaan menyesal karena melakukan kesalahan, atau keinsafan akan kesalahan, yang dirasakan dengan mendalam. Pertobatan adalah berbalik kepada Allah dan kepada hidup yang ditandai oleh terang Allah di dalamnya." ${ }^{14}$ Ini berarti adalah suatu yang tidak dilakukan dengan asal-asalan atau dengan kata lain tidak hanya sekedar penyesalan. Ketika pemuda benar-benar bertobat maka pemuda mengalami pertobatan yang sesungguhnya, dengan demikian mereka menjadi orang Kristen yang bertanggung jawab dengan kehidupan pribadinya dihadapan Tuhan.

\footnotetext{
${ }^{14}$ Sinclair B. Ferguson, Kehidupan Kritsen Sebuah Pengantar Doktrinal (Surabaya: Momentum, 2007), 100.
} 


\section{Tujuan Pertumbuhan}

Pertumbuhan yang ingin dicapai adalah pengetahuan yang benar tentang firman Tuhan. Bila setiap pemuda sudah memiliki pengetahuan yang benar tentang firman Tuhan maka sikap hormat itu ditunjukan dengan cara melakukan Firman Tuhan di dalam kehidupannya setiap hari. Untuk mengalami pertumbuhan paling sedikit ada tiga hal yang perlu dilakukan yaitu:

Pertama, mengadakan saat teduh setiap hari. Setelah mengalami pertobatan itu bukan berarti otomatis akan membuat seseorang akan mengalami pertumbuhan rohani. Melakukan saat teduh yaitu membaca dan merenungkan Firman Tuhan dan berdoa.

Kedua, mengikuti persekutuan Kristen dengan setia. Dengan mengikuti persekutuan yang dilakukan oleh orang Kristen maka orang muda akan dikuatkan dan orang itu akan mengalami pertumbuhan rohani. Persekutuan Kristen ini mencakup kegiatan-kegiatan gereja, kelompok pemahaman Alkitab dan kelompok doa.

Ketiga, menerapkan firman Tuhan dalam kehidupan sehari-hari. Yakobus $1: 22-25$, dalam ayat tersebut firman Tuhan mengajarkan supaya orang percaya menjadi pelaku Firman bukan hanya pendengar. Ini berarti apa yang sudah diteliti melalui saat teduh dan yang didapatkan melalui persekutuan harus diterapkan dalam kehidupan setiap hari. Atau sungguh-sungguh melakukannya dalam kehidupan.

Ketika pemuda melakukan ketiga hal di atas maka pemuda akan mengalami yang namanya pertumbuhan rohani, dengan demikian seorang Pembina pemuda layak dan mampu melayani karena Roh Kudus yang ada dalam diri orang percaya itu akan memberi kekuatan dan perlindungan.

\section{Kesempurnaan Dalam Kristus}

Setiap insan pasti mendambakan dan menginginkan suatu kesempurnaan dalam kehidupannya. Oleh sebab itu, ada banyak cara dan upaya yang dilakukan oleh manusia untuk mencapai kesempurnaan tersebut. Kesempurnaan yang penulis maksudkan di sini bukanlah kesempurnaan yang ditawarkan oleh dunia ini tetapi kesempurnaan dalam Kristus. Dalam Kolose 1 : 28,29, Rasul Paulus memakai beberapa cara untuk membina anggota jemaat yang ada di Kolose. Dalam ayat tersebut menjelaskan Rasul Paulus menasehati dan mengajar, dalam hubungan ini Paulus menceritakan secara khusus pemikirannya mengenai pelayanan jemaat. Ia memahaminya sebagai pemberitaan dan nasihat dan ajaran dengan tujuan untuk memimpin setiap orang kepada kesempurnaan dalam Kristus. 
Ronald W. Leigh, menjelaskan:

"Kesempurnaan ini menunjuk kepada perkara rohani. Kesempurnaan itu dicapai secara bertahap dan meliputi berbagai segi.Ada berupa tahap mengenai kedewasaan dalam Kristus yaitu menjadi seperti Bapa (I Petrus 1:15), menjadi serupa Kristus, lengkap dan dewasa (Efesus 4:13), sepenuhnya di bawah pengaruh Roh Kudus (Galatia 15:16), taat sepenuhnya kepada firman Allah (Yakobus 1:22), tidak ingin menentukan kehendaknya sendiri (Filipi 2:3-8)."

Melihat pernyataan di atas berarti kedewasaan dan kesempurnaan hanya diperoleh melalui Kristus dan hanya diberikan kepada orang yang hidup di dalam Yesus. Jadi Pembina pemuda diwajibkan mengarahkan pemuda kepada kesempurnaan dalam Yesus sehingga mereka bertumbuh dan tidak tersesat dalam menghadapi keadaan dunia yang semakin hari semakin kacau.

\section{METODOLOGI PENELITIAN}

\section{Sejarah berdirinya Pelayanan Pemuda Jemaat Sidu'ung Muara}

Menurut Aing (samaran), waktu kepindahan dari Teras Baru tahun 1996 ke Desa Sidu'ung Muara, Berau banyak hal yang belum berjalan dengan baik seperti pelayanan organ-organ termasuk persekutuan pemuda. Atas himbauan para hamba Tuhan, agar persekutuan pemuda harus dilaksanakan sehingga pada tahun 1997 persekutuan pemuda mulai di bentuk dan dijalankan. ${ }^{16}$ Mulai saat itu persekutuan pemuda berjalan berdasarkan anggaran dasar Rumah Tangga GKII, pada tahun 1997 pemuda GKII Sidu'ung Muara memilih ketua pemuda Aing Njau dan dibantu oleh beberapa anggota pemuda untuk memperjuangkan pelayanan pemuda.

Kondisi saat ini keanggotaan pemuda Jemaat Sidu'ung Muara keseluruhan mencapai 43 anggota pemuda, yang terdiri dari siswa, mahasiswa, wiraswasta dan karyawan perusaahan. Namun, rata-rata kehadiran adalah kurang lebih 36 anggota." ${ }^{17}$ Sebab ada beberapa yang

\footnotetext{
${ }^{15}$ Ronalg W. Leigh, Melayani dengan Efektif (Jakarta: BPK Gununng Mulia, 1991), $10-11$.

${ }^{16}$ Aing, Wawancara Oleh Penulis Sidu'ung Muara, Kalimantan Timur, 7 Juni 2013.

${ }^{17}$ Alung, Wawancara Oleh Penulis Sidu'ung Muara, Kalimantan Timur, 7 Juni 2013.
} 
bersekolah di kota, jika liburan maka jumlah kehadiran akan bertambah pula, ada pula yang hanya lulus SD dan SMP tidak mampu dari segi finansial, sehingga diarahkan oleh orang tua untuk menjadi petani.

\section{Prosedur Penelitian}

\section{Populasi}

Yang menjadi objek penelitian adalah Pembina pemuda-pemudi GKII Jemaat Sidu'ung Muara Berau Kalimantan Timur dengan jumlah Pembina pemuda 6 orang.

\section{Teknik Pengumpulan Data}

Teknik pengumpulan data yang digunakan oleh penulis untuk mendapatkan data yang akurat ialah:

Pertama, pengamatan (observasi). Yang diobservasi pada penelitian ialah mengamati persahabatan, membangun relasi dengan orang tua, pendalaman Alkitab, persekutuan, penginjilan dan bimbingan pribadi berlangsung dengan baik.

Kedua, angket (quisioner). Dalam penelitian ini penulis menggunakan angket tertutup. Pertanyaan-pertanyaan yang diberikan berkaitan dengan penelitian pemuda terhadap pembinaan-pembinaan melalui pendekatan dan pembinaan rohani yang di upayakan oleh Pembina pemuda untuk membimbing, menolong dan menarik mereka untuk terlibat aktif dalam persekutuan dan pelayanan pemuda.

Ketiga, wawancara. "Tanya jawab peneliti dengan nara sumber."18 Wawancara yang dilakukan penulis adalah bertatap muka secara empat mata dan ada juga yang melalui telepon.

\section{Teknik Analisi Data}

Teknik analisa data yang digunakan penulis dalam karya ilmiah ini yaitu interpretasi, yaitu "Penjelasan yang terperinci tentang arti yang sebenarnya dari materi yang dipaparkan." ${ }^{, 19}$ Yaitu dengan cara menafsir data-data supaya mengetahui faktor penyebab pemuda GKII Jemaat Sidu'ung Muara tidak mengalami pertumbuhan rohani. Setelah ditafsir, data-data ini kemudian dijelaskan secara deskriptif untuk menggambarkan dan memaparkan solusi yang dapat diberikan kapada pemuda di GKII Jemaat Sidu'ung Muara, guna meningkatkan pertumbuhan rohani meraka.

\footnotetext{
${ }^{18}$ Kamus Besar Bahasa Indonesia, v. s. "wawancara"

${ }^{19}$ Moh. Nazir, Metode Penelitian (Jakarta: Ghalia Indonesia, 1988), 438. 


\section{ANALISIS HASIL PENELITIAN DAN PEMBAHASAN}

\section{Hasil Penelitian}

Dalam penelitian yang dilakukan penulis, maka hasil data yang diperoleh kemudian diolah dan disimpulkan dalam bentuk tabel. Untuk menganalisa hasil angket, penulis menggunakan teknik persentase dengan rumus sebagai berikut:

$\%=\frac{\mathrm{n}}{\mathrm{N}} \times 100 \%$

Penjelasan rumus ${ }^{20}$

$\%=$ Peresentasi

$n=$ Jumlah Jawaban yang diberikan responden

$\mathrm{N}=$ jumlah responden

Tabel 1. Keberadaan diri sendiri

\begin{tabular}{|c|c|c|c|}
\hline 1. & $\begin{array}{l}\text { Apakah anda sudah sungguh-sungguh menerima } \\
\text { Kristus sebagai Tuhan dan Juruslamat anda secara } \\
\text { pribadi? }\end{array}$ & $\mathrm{n}$ & $\%$ \\
\hline \multicolumn{2}{|r|}{ I } & 6 & 100 \\
\hline \multicolumn{2}{|c|}{ Ragu-ragu } & - & - \\
\hline \multicolumn{2}{|c|}{ Tidak } & - & - \\
\hline & $\mathrm{N}$ & 6 & 100 \\
\hline 2. & $\begin{array}{l}\text { Apakah anda percaya bahwa Yesus sanggup } \\
\text { menyelamatkan anda? }\end{array}$ & $\mathrm{n}$ & $\%$ \\
\hline \multicolumn{2}{|r|}{ ( } & 6 & 100 \\
\hline \multicolumn{2}{|c|}{ Ragu-ragu } & - & \\
\hline \multicolumn{2}{|c|}{ Tidak } & - & \\
\hline \multicolumn{2}{|r|}{$\mathrm{N}$} & 6 & 100 \\
\hline \multirow[t]{5}{*}{3.} & $\begin{array}{l}\text { Apakah anda melakukan saat teduh setiap hari } \\
\text { secara teratur? }\end{array}$ & $\mathrm{n}$ & $\%$ \\
\hline & Ya & 1 & 17 \\
\hline & Kadang-kadang & 4 & 66 \\
\hline & Tidak & 1 & 17 \\
\hline & $\mathrm{N}$ & 6 & 100 \\
\hline \multirow[t]{2}{*}{4.} & $\begin{array}{l}\text { Apakah anda mengikuti setiap ibadah yang } \\
\text { dilakukan dalam persekutuan jemaat Sidu'ung } \\
\text { Muara? }\end{array}$ & $\mathrm{n}$ & $\%$ \\
\hline & $\begin{array}{l}\text { Ya } \\
\text { Kadang-kadang }\end{array}$ & $\overline{6}$ & $\overline{-}$ \\
\hline
\end{tabular}

${ }^{20}$ Muhammad Ali, Penelitian Kependidikan (Bandung: Angkasa, 1985), 184. 


\begin{tabular}{|c|c|c|c|}
\hline \multicolumn{2}{|r|}{ Tidak } & \multirow{2}{*}{$\overline{6}$} & \multirow{2}{*}{-} \\
\hline & $\mathrm{N}$ & & \\
\hline 5. & $\begin{array}{l}\text { Apakah anda, sebagai Pembina pemuda telah } \\
\text { memberikan teladan rohani yang baik? }\end{array}$ & $\mathrm{n}$ & $\%$ \\
\hline \multirow{3}{*}{\multicolumn{2}{|c|}{$\begin{array}{l}\text { Ya } \\
\text { Kadang-kadang } \\
\text { Tidak }\end{array}$}} & 1 & 17 \\
\hline & & 4 & 66 \\
\hline & & 1 & 17 \\
\hline \multicolumn{2}{|c|}{ 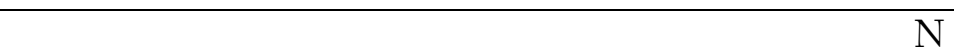 } & 6 & 100 \\
\hline 6. & $\begin{array}{l}\text { Apakah anda adalah seorang yang dapat } \\
\text { bersosialisasi dengan baik terhadap lingkungan? }\end{array}$ & $\mathrm{n}$ & $\%$ \\
\hline \multirow{3}{*}{\multicolumn{2}{|c|}{$\begin{array}{l}\text { Ya } \\
\text { Kadang-kadang } \\
\text { Tidak }\end{array}$}} & - & - \\
\hline & & 4 & 66 \\
\hline & & 2 & 34 \\
\hline \multirow{2}{*}{\multicolumn{2}{|c|}{$\begin{array}{l}\text { Apakah anda telah menunujukan sifat saling } \\
\text { menghargai terhadap pemuda? }\end{array}$}} & 6 & 100 \\
\hline & & $\mathrm{n}$ & $\%$ \\
\hline \multirow{3}{*}{\multicolumn{2}{|c|}{$\begin{array}{l}\text { Ya } \\
\text { Kadang-kadang } \\
\text { Tidak }\end{array}$}} & l & 17 \\
\hline & & 4 & 66 \\
\hline & & 1 & 17 \\
\hline \multicolumn{2}{|r|}{$\begin{array}{ll} & \mathrm{N}\end{array}$} & 6 & 100 \\
\hline 8. & $\begin{array}{l}\text { Apakah anda telah melaksanakan tugas dengan } \\
\text { penuh tanggung jawab? }\end{array}$ & $\mathrm{n}$ & $\%$ \\
\hline \multirow{3}{*}{\multicolumn{2}{|c|}{$\begin{array}{l}\text { Ya } \\
\text { Kadang-kadang } \\
\text { Tidak }\end{array}$}} & 3 & 50 \\
\hline & & 3 & 50 \\
\hline & & - & - \\
\hline & $\mathrm{N}$ & 6 & 100 \\
\hline
\end{tabular}

Berdasarkan tabel di atas pertanyaan nomor 1 dan 2 diperoleh keterangan bahwa dari 6 responden, 6 (100\%) orang menjawab bahwa mereka sudah menerima Kristus secara pribadi dan mereka percaya bahwa Yesus sanggup menyelamatkan mereka. Dari hal ini dapat diketahui bahwa semua pembina pemuda telah menerima Kristus sebagai Tuhan dan Juruslamat secara pribadi, dan mereka percaya bahwa Tuhan sanggup menyelamatkan mereka.

Pada pertanyaan nomor 3 diperoleh keterangan bahwa dari 6 responden, $1(17 \%)$ responden yang melakukan saat teduh setiap hari secara teratur, 4 (66 \%) responden yang kadang-kadang bahwa mereka melakukaan saat teduh setiap hari secara teratur. Ada 1 (17 \%) responden yang mengatakan bahwa tidak pernah melakukan saat teduh setiap hari. Dari hasil ini dapat disimpulkan bahawa lebih dari setengah Pembina pemuda tidak dengan sungguh-sungguh memiliki hubungan pribadi yang erat dengan Tuhan, ini terlihat juga dari pengamatan dan 
hasil wawancara penulis dengan seorang pembina pemuda Uling nama samaran mengatakan, "Jujur saya sebagai seorang pembina pemuda jarang melakuan saat teduh secara pribadi dengan Tuhan. Bahkan dalam satu minggu tidak pernah" ${ }^{21}$ Kesimpulan dalam bagian ini pembina pemuda perlu meningkatkan kedisiplinannya dalam melakukan saat teduh secara teratur karena hal ini akan berdampak besar dalam tugas pelayanan terhadap pertumbuhan rohani pemuda.

Pada pertanyaan nomor 4 diperoleh dari 6 responden mengatakan bahwa semua (100\%) respoden mengatakan bahwa mereka kadangkadang mengikuti setiap persekutuan yang dilakukan di Sidu'ung Muara. Dari hasil ini seorang Pembina pemuda sangat dituntut untuk mendisiplinkan diri untuk mengikuti persekutuan. Sebab kalau tidak maka Pembina pemuda akan menjadi batu sandungan bagi anggota pemuda.

Pertanyaan nomor 5 diperoleh keterangan dari 6 responden hanya ada $1(17 \%)$ responden yang mengatakan memberikan teladan rohani yang baik, 4 (66 \%) responden mengatakan bahwa kadang-kadang memberikan teladan rohani yang baik. Ada 1 (17\%) responden yang mengatakan bahwa tidak dapat memberikan teladan rohani yang baik. Dapat diketahui bahwa Pembina pemuda pada umumnya tidak dapat menjadi teladan bagi anggotanya.

Pada pertanyaan nomor 6 diperoleh dari 6 rasponden 4 (66\%) responden yang mengatakan bahwa mereka kadang-kadang dapat bersosialisasi dengan baik terhadap lingkungannya, 2 (34\%) responden yang mengatakan bahwa mereka tidak bisa bersosialisasi dengan baik terhadap lingkungan. Dapat diketahui Pembina pemuda kurang sekali dalam membangun hubungan dengan lingkungan

Pertanyaan nomor 7 diperoleh dari 6 responden, ada 1 (17\%) responden mengatakan bahwa dapat menunjukan sifat saling menghargai terhadap orang lain, ada 4 (66\%) responden mengatakan bahwa kadang-kadang dapat menunjukan sifat saling menghargai, 1 (17 \%) responden mengatakan tidak dapat menunjukan sifat saling menghargai.

Pertanyaan nomor 8 diperoleh keterangan dari 6 responden 3 (50 $\%)$ responden yang mengatakan telah melaksanakan tugasnya dengan setia penuh tanggung jawab, 3 (50 \%) responden mengatakan bahwa kadang-kadang melaksanakan tugas dengan setia dan penuh tanggung jawab. Jadi terlihat bahwa Pembina pemuda pada umumnya perlu tingkatkan lagi dalam melaksanakan tugas pelayanannya dengan setia dan penuh tanggung jawab.

\footnotetext{
${ }^{21}$ Uling, Wawancara Oleh Penulis, Sidu’ung Muara Berau, Kalimantan Timur, 7 Juni 2013.
} 
Tabel 02. Strategi Pembinaan Rohani Pemuda

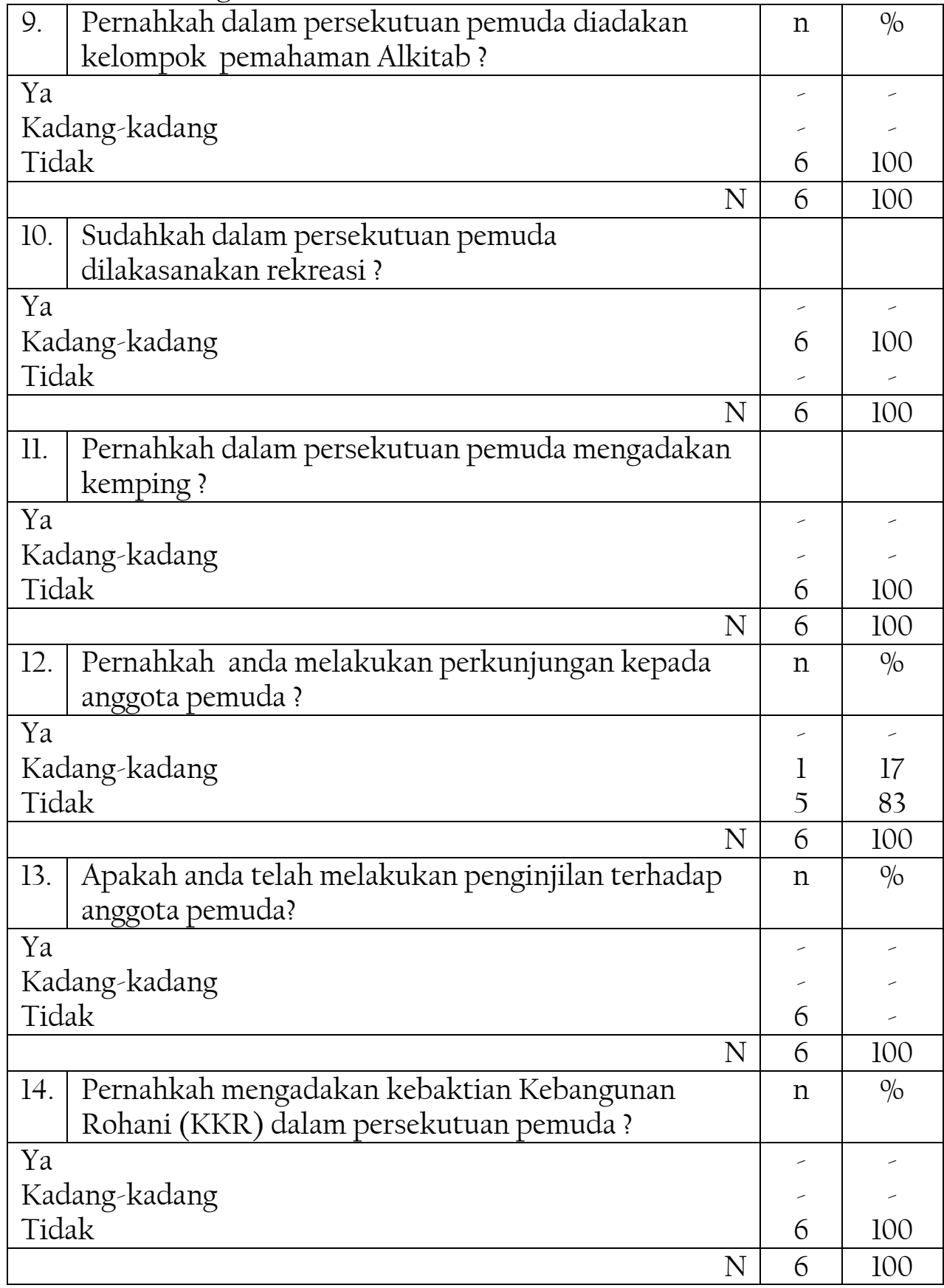

Pertanyaan nomor 9 diperoleh dari 6 responden, 6 respon yang menyatakan bahwa dalam dalam persekutuan pemuda tidak pernah dilakukan kelompok pendalaman Alkitab. Maka Pembina 
memaksimalkan strategi kelompok pendalaman Alkitab, karena strategi ini dapat meningkatkan pertumbuhan rohani pemuda.

Pada pertanyaan nomor 10 diperoleh dari 6 responden 6 respoden mengatakan bahwa merka kadang-kadang melaksanakan rekreasi dalam persekutuan pemuda. Maka, Pembina pemuda perlu menata atau membuat bentuk ibadah itu sekreatif mungkin sehingga anggota pemuda tertarik untuk ikut dalam bersekutuan, melalaui persekutuan mereka dibina dengan demikian pemuda dapat bertumbuh secara rohani. Pertanyaan nomor 11 diperoleh dari 6 responden 6 responden mengatakan bahwa dalam persekutuan pemuda tidak perna dilakukan kemping. Oleh sebab itu, perlu untuk Pembina pemuda menyusun program untuk melaksanakan kegiatan kemping. Karena melalui kegiatan ini pembinaan terhadap pemuda akan jadi efektif.

Kemping merupakan pembinaan yang efektif dalam pembinaan generasi muda Paul Suparno mengatakan, "Dalam kemping ini kita mau menghadap Tuhan agar lebih mengenal kehendak-Nya dan merasakan kasih-Nya kepada kita. Kita dididik untuk lebih menanggapi kasih dan sapaan-Nya, sehingga hidup sungguh-sungguh sesuai dengan kehendakNya." ${ }^{22}$ Ini berarti bahwa kemping dapat memberikan suatu sumbangsih yang sangat besar bagi pertumbuhan rohani pemuda.

Pertanyaan nomor 12 diperoleh dari 6 responden, 1 responden mengatakan bahwa kadang-kadang melakukan perkunjungan terhadap anggota kaum muda. 5 respoden mengatakan bahwa mereka tidak pernah melakukan perkunjungan terhadap pemuda. Maka strategi perkunjungan ini harus dimaksimalkan sebab melalui perkunjungan yang efektif dapat memikat hubungan yang baik antara Pembina dengan anggota pemuda, kemudian melalui persahabatan ini pembinaan kerohanian akan efektif

Pertanyaan 13 diperoleh dari 6 responden 6 respoden mengatakan tidak pernah melakukan penginjilan baik pengijilan secara pribadi maupun secara umum kepada anggota pemuda. Pembinaan pemuda seharusnya melaksanakan penginjilan karena ini menjadi tanggung jawab sebagai orang Kristen apalagi sebagai seorang Pembina pemuda.

Sehubungan dengan penginjilan, alasan yang membuat Pembina pemuda tidak melaksanakan tugas ini jawaban mereka berbeda-beda, namun pada intinya mereka tidak mengadakan penginjilan ialah karena tidak berani atau tidak bisa menginjil. Tidak memunyai keberanian untuk memberitakan injil kepada orang lain. Padahal menurut mereka ada begitu banyak pemuda yang perlu diinjili.

Pertanyaan nomor 14 diperoleh dari 6 responden, 6 responden mengatakan bahwa tidak pernah dilakukan KKR dalam persekutuan

\footnotetext{
${ }^{22}$ Paul Suparno, Retret Untuk Mahasiswa (Yogyakarta: Kanisius, 1990), 20.
} 
pemuda, perlu pembina pemuda memaksimalkan sterategi pembinaan kerohanian pemuda melalui KKR. J. Wesley Brill menegaskan, "Tujuan mengadakan kebangunan Rohani ialah untuk menemplak dosa, supaya orang menyadari bahwa dirinya berdosa, lalu bertobat dan mengambil tindakan terhadap apa yang telah didengarnya serta berjalan menurut kehendak Allah dalam kehidupan mereka." ${ }^{23}$

${ }^{23}$ J. Wesley Brill, Tafsiran Timotius dan Titus (Bandung: Kalam Hidup, 1978), 185. 


\section{PENUTUP}

\section{Kesimpulan}

Kesimpulan karya ilmiah ini adalah:

Pertama, penghambat pertumbuhan rohani pemuda GKII Sidu'ung Muara adalah karena belum terjadi pertobatan yang sesungguhnya di kalangan pemuda.

Kedua, fakta di lapangan menunjukkan adanya kendala-kendala yang menghambat dalam pertumbuhan rohani pemuda GKII Sidu'ung Muara yaitu: 1) kurangnya dedikasi seorang Pembina pemuda terhadap pelayanan pemuda. 2) Kurangnya persekutuan. 3) Lingkungan sosial yang kurang mendukung pertumbuhan rohani pemuda. 4) Program pelayanan pemuda kurang menarik.

Ketiga, beberapa upaya atau strategi pembinaan yang efektif dalam meningkatkan kualitas kerohanian pemuda adalah dengan melakukan perkunjungan secara teratur, melalui pemahaman Alkitab, mengadakan retret, menyelenggarakan KKR, Penginjilan Pribadi dan menata persekutuan dengan kreatif. 


\section{KEPUSTAKAAN}

Alkitab

Alkitab. Jakarta: Lembaga Alkitab Indonesia, 2006.

Tafsiran Alkitab Masa Kini 3 Jakarta: BPK Gunung Mulia, 1992.

Buku-buku

Alli, Muhammad. Penelitian Kependidikan. Bandung: Angkasa, 1985.

Brill, Wesley. Tafsiran Timotius dan Titus. Bandung: Kalam Hidup, 1978.

Ferguson, Sinclair B. Kehidupan Kritsen Sebuah Pengantar Doktrinal.

Surabaya: Momentum, 2007.

Leigh, Ronalg W. Melayani dengan Efektif. Jakarta: BPK Gununng Mulia, 1991.

Nazir, Moh. Metode Penelitian. Jakarta: Ghalia Indonesia, 1988.

Raines dan Richardso W., Azas-Azas Alkitab Bagi kaum Muda. Bandung: Kalam Hidup, 1995.

Richardson dan Raines, Asas-Asas Alkitab Bagi Kaum Muda (Bandung: Kalam Hidup, 1980

Setiawani, Go Mary. Pembaharuan Mengajar. Bandugn: Kalam Hidup, 2004.

Shelton, M. Charles. Menuju Kedewasaan Kristen. Yogyakarta: Kanisius, 1988.

Sudjarwo, PH. Metodeologi Penelitian Sosial. Bandung: Mandar Maju, 2001.

Suparno, Paul. Retret Untuk Mahasiswa. Yogyakarta: Kanisius, 1990.

Wawancara

Aing, Wawancara Oleh Penulis Sidu'ung Muara, 7 Juni 2013.

Alung, Wawancara Oleh Penulis Sidu'ung Muara, 7 Juni 2013.

Baun, wawancara oleh Penulis, Sidu'ung Muara, 6 Juni 2013.

Iban, Wawancara oleh Penulis, Sidu'ung Muara, 5 Juni 2013

Ketua pemuda Sidu'ung Muara, wawancara oleh Penulis, Sidu'ung Muara 5 juni 2013.

Kule, pengurus Jemaat, Wawancara oleh Penulis, Sidu'ung Muara, 6 Juni 2013.

Laing, wawancara oleh Penulis, Sidu'ung Muara, 5 Juni 2013.

Sulau, wawancara oleh Penulis, Sidu'ung Muara, 6 Juni 2013.

Ubang, wawancara oleh penulis, Sidu'ung Muara, 5 Juni 2013.

Ulan, wawancara oleh penulis, Sidu'ung, 5 Juni 2013.

Uling, Wawancara Oleh Penulis Sidu'ung Muara Berau, 7 Juni 2013. 